\title{
Effect of lupin alkaloid fractions level on performance and blood parameters in chickens
}

\section{Lidia Uziębło ${ }^{1}$, K. Gulewicz ${ }^{2}$, Zofia Tarasewicz ${ }^{1}$, M. Bednarczyk ${ }^{3}$, Danuta Szczerbińska ${ }^{1}$ and M. Ligocki ${ }^{1}$}

\author{
'Szczecin Agricultural University, Department of Poultry Breeding \\ Dr Judyma 20, 71-460 Szczecin. Poland \\ ${ }^{2}$ Institute of Bioorganic Chemistry, \\ Polish Academy of Sciences \\ Noskowskiego 12/14, 61-704 Poznan, Poland \\ ${ }^{3}$ Poultry Research Center \\ Zakrzewo, 62-069 Palędzie, Poland
}

(Received 25 October 1995; accepted 9 July 1996)

\section{ABSTRACT}

Broiler chickens reared from 3 to 8 weeks of age were fed per os on extract or, differing in chemical composition fractions of the extract $\left(\mathrm{A}_{0}-\mathrm{A}_{6}\right)$ from bitter lupin ( $L$. angustifolius var. Mirela) seeds (Experiment 1), the extract and its selected fractions $\left(A_{1}, A_{1}, A_{5}\right)$ from the seeds of Mirela as well as extract from sweet lupin var. Emir (Experiment 2). The extracts from bitter lupin harvested in two consecutive years, used in the experiments, differed in alkaloid content. The cxtracts and fractions did not negatively affect growth, feed intake or health of the chickens. Only fraction $\mathrm{A}_{5}$ (alkaloid hydrochlorides) used in Experiment 2, which was from extract with higher alkaloid content, reduced $(\mathrm{P}<0.01)$ body weight gain of the chickens.

The $T_{3}$ level in the peripheral blood serum was the lowest in the birds receiving fractions containing sugars $\left(A_{3}\right)$ and the highest in the group receiving alkaloid hydrochlorides $\left(A_{5}\right)$. The $T_{4}$ level was the highest in the chickens receiving extract from sweet lupin. The extracts and fractions had no effect on the red blood cell count while leukograms showed only undirected variation, except for basophil and eosinophil in blood of which level was higher in experimental than control birds.

KEY WORDS: broilers, lupin, alkaloids, hormones, blood morphology

\section{INTRODUCTION}

The content of lupin seeds in feed mixtures for poultry is limited by lower, compared to other high protein plant components, content of sulphur- 
containing amino acids, the presence of undigestible polysaccharides in the seed coat and, above all, the presence of antinutritional substances. The latter include alkaloids and $\alpha$-galactosides which are not digested by the birds due to the lack of proper enzyme. The chinolysidine alkaloids in the lupin seeds of bitter varieties worsen the taste properties of the feed and reduced intake which leads to slower growth rate of the animals and reduced performance. It is difficult to explicitly determine whether lower performance is due to reduced feed intake or to the specific effect of alkaloids on the animal organism.

The elaboration of a method for the debittering of lupin seeds allowed to obtain an extract and its different fractions containing various substances, and to determine the effect of these substances on the animal organism (Gulewicz, 1991; Stobiecki and Gulewicz, 1991 ). The extract contains sugars, mostly of the raffinose group ( $50 \% \mathrm{DM})$, nitrogen compounds, free alkaloids, amino-acids, peptides, polyamines and other compounds (together ca $30 \%$ DM) as well as non-volatile organic acids and their derivatives, sterols and mineral compounds (Markiewicz,1988; Hill and Pastuszewska,1993; Stobiecki,1993). It has been found that extracts from $L$. albus and $L$. angustifolius seeds, containing $10 \%$ alkaloids in their DM are not toxic (Stobiecki et al., 1993) but are immunosuppressive (Błaszczyk et al., 1994). An extract from L. angustifolius var. Mirela (bitter) introduced into duck eggs resulted in lowered hatching and statistically significant changes in embryonic blood, characteristics of haemolytic erythropenia, decreased number of erythrocytes and haemoglobin content. The injection of extract and the fraction containing alkaloid hydrochlorides from Mirela lupin into the hen eggs also reduced the rate of hatching and had

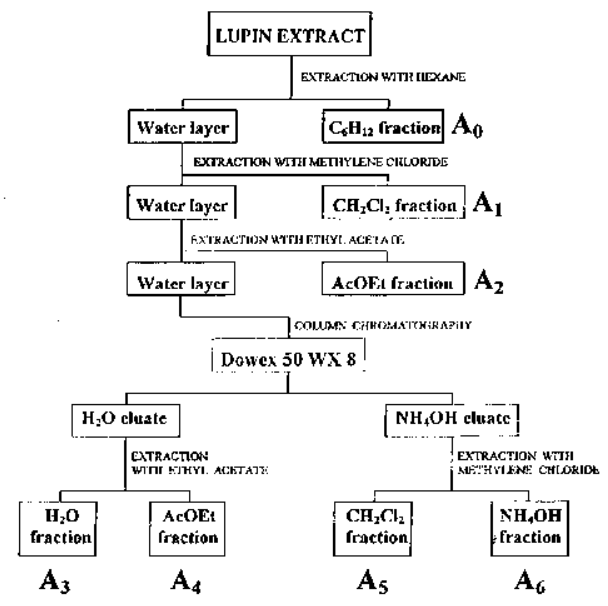

Figure 1. Fractionation scheme of bitter lupin extracts 
a negative effect on the level of thyroid hormones of the chicks, whereas the fraction containing peptides and sugars had a positive effect on rate of hatching (Bednarczyk et al., 1995). Extracts from bitter lupin seeds (var. Mirela and Bac) administered per os reduced growth rate of the chickens. They did not have any effect on rate of lay in hens or physical properties of the eggs but reduced the percentage of fertilizations and rate of hatching. They also caused changes of some blood indices, e.g. haematocrit, cell volume, number of leukocytes and thrombocytes (Uziębło et al., 1995).

\section{MATERIAL AND METHODS}

\section{Preparation of extracts and fractions}

Bitter lupin seeds (var. Mirela) were from the harvests of 1993 and 1994 and the seeds of sweet lupin (var. Emir) from the harvest of 1994 at the plant breeding centers Wiatrowo and Przebedowo. The extracts were obtained by a method elaborated by Gulewicz, (1991) which involves the debittering of whole seeds (with coats) in an aqueous solution of ethanol. The extracts contain all compounds in natural form. The extracts of both parties of seeds were separated into 7 fractions $\left(\mathrm{A}_{0}-\Lambda_{6}\right)$ (Figure 1).

\section{Experimental design}

The experiments were performed on 270 and 288 broiler chickens in Experiments 1 and 2, respectively. The chickens were reared in standard conditions and were fed during the first two weeks of life with DKA-starter mixture and then up to week 8 with Grower and Finisher mixtures. Protein and energy content in the mixtures was in accordance with Nutrient Requirements of Poultry (1993).

At the end of the second week of life the chickens were divided into 9 feed groups in 2 repetitions in Experiment 1 and into 6 groups of 3 repetitions in Experiment 2. The number of birds in each group in both experiments was 30 and 48 , respectively. The type of extract and fraction administered to the birds in the individual feed groups in both experiments is given in Table 1. The extracts and fractions were administered to the birds from the third week of life daily per os with wheat flour (Experiment 1) or every second day (Experiment 2). Chickens of the control group received wheat flour or mixture with addition of water. The daily dose of the extracts and fractions corresponded to the amount of alkaloids taken in by the chickens in mixture containing $15 \%$ lupin seeds. 
TABLE 1

Experimental design

\begin{tabular}{|c|c|c|c|c|c|}
\hline \multicolumn{3}{|c|}{ Experiment 1} & \multicolumn{3}{|c|}{ Experiment 2} \\
\hline Group & $\begin{array}{l}\text { Extract or } \\
\text { fraction }\end{array}$ & $\begin{array}{l}\text { Compounds in } \\
\text { fractions from } \\
\text { bitter lupin seed } \\
\text { extract (Lupinus L., } \\
\text { var. Mirela }{ }^{a} \text { ) }\end{array}$ & Group & $\begin{array}{l}\text { Extract or } \\
\text { or fraction }\end{array}$ & $\begin{array}{l}\text { Compounds in fractions } \\
\text { from lupin seed extract } \\
\text { (var. Mirela }{ }^{b} \text { ) }\end{array}$ \\
\hline I & control & - & I & control & - \\
\hline II & fraction $A_{0}$ & fatty acids, lipids & II & fraction $A_{1}$ & $\begin{array}{l}\text { free alkaloids, their ester } \\
\text { and glucoside derivatives }\end{array}$ \\
\hline III & fraction $A_{1}$ & $\begin{array}{l}\text { free alkaloids, their ester } \\
\text { and glucoside } \\
\text { derivatives }\end{array}$ & III & Traction $\mathrm{A}_{3}$ & $\begin{array}{l}\text { sugars of the raffinose } \\
\text { group }\end{array}$ \\
\hline IV & fraction $\mathrm{A}_{2}$ & $\begin{array}{l}\text { phenolic compounds, } \\
\text { Krebs cycle carboxylic } \\
\text { acids }\end{array}$ & IV & fraction $A_{5}$ & alkaloids hydrochlorides \\
\hline V & fraction $\mathrm{A}_{3}$ & $\begin{array}{l}\text { sugars of the raffinose } \\
\text { group }\end{array}$ & V & $\begin{array}{l}\text { extract from } \\
\text { var. Mirela }\end{array}$ & $\begin{array}{l}\text { all group of compounds } \\
\text { mentioned in Exp. } 1 \text { and } \\
\text { other unidentified } \\
\text { compounds }\end{array}$ \\
\hline VI & fraction $\mathrm{A}_{4}$ & $\begin{array}{l}\text { glycosides, nucleosides } \\
\text { of purine and pyrimidine } \\
\text { bases }\end{array}$ & VI & $\begin{array}{l}\text { extract from } \\
\text { var. Emir }\end{array}$ & as above \\
\hline $\begin{array}{l}\text { VII } \\
\text { VIII } \\
\text { IX }\end{array}$ & $\begin{array}{l}\text { fraction } A_{5} \\
\text { fraction } A_{6} \\
\text { extract }\end{array}$ & $\begin{array}{l}\text { alkaloid hydrochlorides } \\
\text { peptides, amino acids } \\
\text { all groups of chemical } \\
\text { compounds listed above } \\
\text { and other unidentificd } \\
\text { compounds }\end{array}$ & & & \\
\hline
\end{tabular}

" - harvest in 1993

b - harvest in 1994

The daily doses of alkaloids administered with the lupin var. Mirela seeds extract ranged in Experiment 1 from 72.2 (in week 3) to $206.8 \mathrm{mg} /$ bird (in week 8) and in Experiment 2 from 143.0 to $405.5 \mathrm{mg} / \mathrm{bird}$, respectively. The doses of Emir extract ranged from 7.4 to $21.1 \mathrm{mg} /$ bird. In Experiment 2, at the end of the 8th of week of rearning blood was taken before morning feeding from 9 birds of each group for haematological studies and to determine the content of triiodothyronine $\left(\mathbf{T}_{3}\right)$ and thyroxine $\left(\mathbf{T}_{4}\right)$ in peripheral blood serum.

The chickens were weighed on the third and eighth weeks of life and feed intake and growth rate were estimated. 
The content of nutrients in the diets were determined by standard methods (Skulmowski, 1974). Amino acid content was determined with Beckman Multichrome B analyzer, sulphur amino acids - after their oxidation. Erythrocytes, leukocytes and thrombocytes were determined in Burker chamber, haematocrit by the microhaematocrit method and haemoglobin content by the cyanomethemoglobin method. The percentage of white blood cells was estimated from differentiation of 100 leukocytes in blood smear (Bomski,1989). Hormone level was determined by a radioimmunological method with the use of kits RIA-T 3 MI-86 and RIA-T 4 MI-88 produced by OP and DI in Świerk (Poland).

The results were elaborated statistically with the use of the method of variance analysis and multiple range test.

\section{RESULTS $\Lambda$ ND DISCUSSION}

The chemical composition of lupin seeds and calculated amount of administered alkaloids, expressed as their content in feed, are presented in Table 2.

The chickens got adapted in short time to the administration of extract or its fraction-containing flour. The growth rate of the birds differed between both experiments (Table 3) - the chickens grew very fast in the third week in Experiment 1.

In Experiment 1 the extract and its fractions had no significant effect on growth rate of the chickens between 3 and 8 weeks of life. It is not easy to explain the slightly lower body weight of the chickens (statistically insignificant difference) in group $\mathrm{V}$, fed with fraction $\mathrm{A}_{3}$ containing sugars. This result was not confirmed in Experiment 2, in which the lowest body weight $(\mathrm{P}<0.01)$ was found in the chickens receiving fraction $\mathrm{A}_{5}$ containing alkaloids in the form of hydrochlorides (group IV). The reason for the different response of the chickens to this fraction in Experiments 1 and 2 may have been the higher level of alkaloids in the fraction used in Expriment 2 from seeds var. Mirela harvested in 1994, which contained more alkaloids than the seeds from the harvest of 1993. It can be assumed that at higher concentration, the alkaloids in the form of hydrochlorides in fraction $\mathrm{A}_{5}$ (Expriment 2) are tolerated by the chickens worse than the alkaloids occurring in the extract in natural form.

Other authors found greater toxicity of fractions $A_{5}$ and $A_{1}$ from var. Mirela seeds, which contained different forms of alkaloids, than of extracts from the seeds of other sweet and bitter varieties (Stobiecki et al., 1993; Blaszczyk et al., 1994). 
Chemical composition of lupin seeds* (in DM) and alkaloid content

Experiment I

\begin{tabular}{|c|c|c|c|c|c|c|c|}
\hline & \multicolumn{7}{|c|}{ Lupin seeds } \\
\hline & \multicolumn{5}{|c|}{ var. Mirela } & \multirow{2}{*}{\multicolumn{2}{|c|}{$\begin{array}{l}\text { var. Emir } \\
\text { experiment II }\end{array}$}} \\
\hline & \multicolumn{2}{|c|}{ experimet $I^{a}$} & \multicolumn{3}{|c|}{ experiment $\mathrm{II}^{\mathrm{b}}$} & & \\
\hline Crude protein, \% & \multicolumn{2}{|r|}{34.4} & \multicolumn{3}{|c|}{35.0} & \multicolumn{2}{|c|}{34.6} \\
\hline Lys, $\mathrm{g} / 16 \mathrm{gN}$ & \multicolumn{2}{|r|}{3.7} & \multicolumn{3}{|c|}{3.6} & \multicolumn{2}{|c|}{3.8} \\
\hline Met, $\mathrm{g} / 16 \mathrm{gN}$ & \multirow{2}{*}{\multicolumn{2}{|c|}{1.0}} & \multicolumn{3}{|c|}{0.9} & \multicolumn{2}{|c|}{1.1} \\
\hline Cys, g/16 gN & & & \multicolumn{3}{|c|}{1.5} & \multicolumn{2}{|c|}{1.2} \\
\hline Ether extract & \multicolumn{2}{|r|}{$\begin{array}{l}1.5 \\
4.9\end{array}$} & \multirow{2}{*}{\multicolumn{3}{|c|}{$\begin{array}{r}4.9 \\
17.6\end{array}$}} & \multicolumn{2}{|c|}{4.7} \\
\hline Crude fibre, $\%$ & \multicolumn{2}{|r|}{17.8} & & & & \multicolumn{2}{|c|}{17.2} \\
\hline Alkaloids, \% & \multicolumn{2}{|r|}{1.000} & \multicolumn{3}{|c|}{2.010} & \multicolumn{2}{|c|}{0.104} \\
\hline \multirow[t]{3}{*}{ Kind of alkaloids } & \multirow{2}{*}{\multicolumn{2}{|c|}{$\underset{13-\mathrm{La}}{\mathrm{OH} \mathrm{La}}$}} & \multicolumn{3}{|c|}{$\mathrm{La}$} & \\
\hline & & & \multirow{2}{*}{\multicolumn{3}{|c|}{$\begin{array}{c}13-\mathrm{OH} \mathrm{La} \\
\mathrm{A}\end{array}$}} & & \\
\hline & \multicolumn{2}{|r|}{ A } & & & & \multicolumn{2}{|c|}{$\begin{array}{c}\text { 13-OH La } \\
\text { A }\end{array}$} \\
\hline \multicolumn{8}{|c|}{$\begin{array}{l}\text { Alkaioids content } \\
\text { in feed mixtures (theorectical } \\
\text { content at } 15 \% \text { content } \\
\text { of lupin seed in the } \\
\text { mixture) }\end{array}$} \\
\hline \multicolumn{8}{|c|}{$\begin{array}{l}\text { Kind of fractions and its } \\
\text { content (\%) in DM of extract } \\
\text { from bitter lupin var. }\end{array}$} \\
\hline Mirela $^{a}$ & $\begin{array}{c}\Lambda_{0} \\
0.50\end{array}$ & $\begin{array}{l}\mathrm{A}_{1} \\
1.3\end{array}$ & $\begin{array}{c}\Lambda_{2} \\
0.60\end{array}$ & $\begin{array}{c}\mathrm{A}_{3} \\
68.7\end{array}$ & $\begin{array}{l}\mathrm{A}_{4} \\
3.3\end{array}$ & $\begin{array}{l}\mathrm{A}_{5} \\
6.6\end{array}$ & $\begin{array}{c}\mathrm{A}_{6} \\
19.2\end{array}$ \\
\hline
\end{tabular}

* according to Institute of Bioorganic Chemistry, Poznań

" harvest in 1993

${ }^{b}$ harvest in 1994

La - lupanine, 13-OH La-13 - hydroxylupanine, A - angustifoline

The lack of effect of the extract and its fractions on the growth of the chickens in Experiment 1 (Table 3) confirms the results of Bednarczyk et al. (1995) on chicken embryos. The administration of extracts and fractions also did not depress the utilization of feed (Table 3). The ratio of feed to weight gain in Experiment 1 was from 1.95 (group II) to $2.27 \mathrm{~kg}$, (group I, control), and in Experiment 2 from 2.03 (group II) to 2.11 (group IV-VI) and 2.08 in the control group.

The obtained results do not explicitly indicate the negative effect of the administration of compounds isolated from lupin seeds on the health status of chickens. In both experiments small losses of birds occurred in the groups receiving extract from var. Mirela lupin seeds. The relatively high percentage of deaths in Experiment 1 in several of the experimental groups, in particular in the 
要

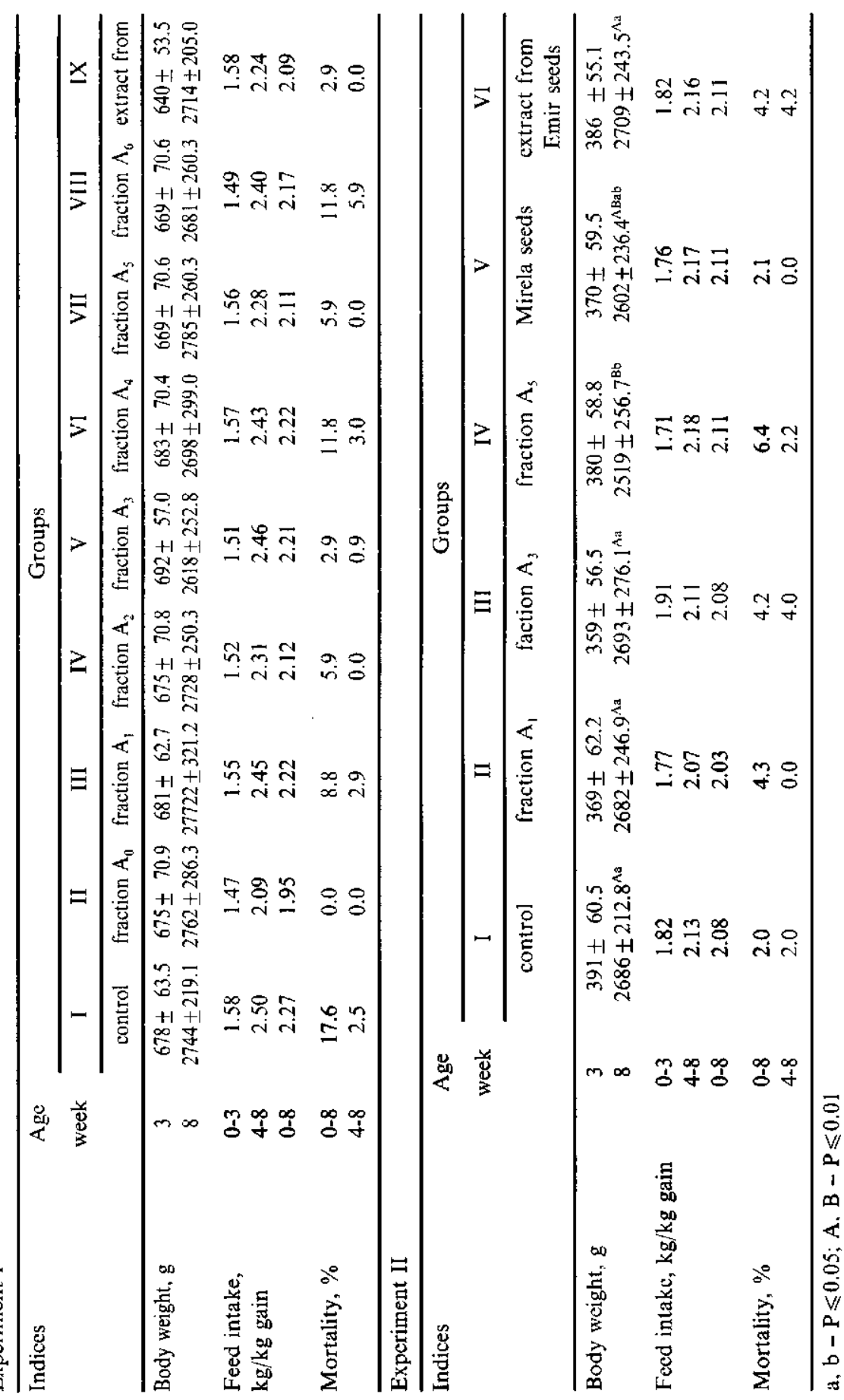


control group, was not caused by pathological changes. The largest number of deaths was recorded between weeks 0 and 3 (Table 3 ). The growth performance of the chickens indicate the absence of any effect of fractions $A_{0}, A_{1}, A_{2}, A_{4}$ and $A_{6}$ isolated from the extract from bitter lupin seeds var. Mirela.

The level of the thyroid hormones: triiodothyronine $\left(T_{3}\right)$ and thyroxine $\left(T_{4}\right)$ in the peripheral blood serum of the chickens in most of the experimental groups differed from the control birds, though, due to high individual variation the significance of the difference was not confirmed (Table 4). The content of $T_{3}$ was the lowest in group III $(0.60)$ which obtained the fraction containing sugars $\left(\mathrm{A}_{3}\right)$ and the highest in group IV $(2.55 \mathrm{nmol} / \mathrm{l})$ which received alkaloid hydrochlorides. The content of $\mathrm{T}_{4}$ ranged from $89 \mathrm{in}$ group IV to $293 \mathrm{nmol} / 1$ in group VI (extract from var. Emir). The closest to the control group were the indices obtained in group II (fraction $A_{1}$ ) which may indicate that alkaloids in natural form do not affect the level of either of the hormones. The results are partly compatible with the results of Kliber et al. (1994) who found that the administration per os to rats of extract and fraction $\mathrm{A}_{5}$ from bitter $L$. angustifolius affects the secretion of insulin, thyroxine and triiodothyronine and that the effect seems to be caused not only by alkaloids. The compatibility of our results and those of the above cited author concern the effect of fraction $\mathrm{A}_{5}$ administered to group IV in Experiment 2, on the level of hormones. Possible disturbances of homeostasis caused by the above could have affected the growth of the broilers (statistically significant slightly lower body weight of the chickens of this group). The administration of extract from Mirela lupin seeds (group V) affected the hormone level and growth of the birds to a lower degree than fraction $\mathrm{A}_{5}$ (group IV).

Statistically significant differences between the level of both hormones in the embryonic blood of control group and those treated with extracts or some of the fractions from var. Mirela and Emir lupin were also found by Bednarczyk et al. (1995). The ratio of $T_{3}$ to $T_{4}$ (Table 4) differed the most between group VI (0.006) and II (0.005) and the control group (0.017). This observation is difficult to explain since both groups received the extract from sweet lupin var. Emir and "sugar" fraction $A_{3}$, respectively.

TABLE 4

$\mathrm{T}_{3}$ and $\mathrm{T}_{4}$ contents in blood serum

\begin{tabular}{lcccccc}
\hline Indices & \multicolumn{7}{c}{ Groups } \\
\cline { 2 - 7 } & I & II & Ill & IV & V & VI \\
\hline $\mathrm{T}_{3}$ & $1.93 \pm 1.21$ & $1.58 \pm 0.75$ & $0.60 \pm 0.34$ & $2.55 \pm 0.75$ & $2.02 \pm 1.32$ & $1.19 \pm 0.14$ \\
$\mathrm{~T}_{4}$ & $167 \pm 77$ & $175 \pm 161$ & $111 \pm 39$ & $89 \pm 48$ & $134 \pm 81$ & $293 \pm 209$ \\
$\mathrm{~T}_{3} / \mathrm{T}_{4}$ & 0.017 & 0.014 & 0.005 & 0.040 & 0.025 & 0.006 \\
\hline
\end{tabular}


The number of erythrocytes (RBC) in the blood of the chickens did not differ significantly between the groups (2.23-2.51 x $\left.10^{6} / \mathrm{mm}^{3}\right)$, though the RBC level in all experimental groups was slightly higher than for the control birds. Haemoglobin $(\mathrm{Hb})$ content was from 7.81 to $8.50 \mathrm{~g} \%$ and haematocrit from 27.3 to $29.1 \%$. The absence of significant differences in $\mathrm{Hb}$ and $\mathrm{RBC}$ as well as of any difference in mean blood cell volume indicates that the extracts or fractions used did not have any negative effect on the red blood cell count of the birds. This is in agreement with the studies of Bednarczyk et al. (1995) who did not find any negative effect of var. Mirela lupin extract on RBC and $\mathrm{Hb}$ level in embryonic blood. It was, however, found that salts of the alkaloids $\left(\mathrm{A}_{5}\right)$ reduced content of both these blood components compared to the control group. Due to high individual variation of white blood cell count, the differences between groups were statistically insignificant (Table 5). The number of leukocytes differed very little among groups $\left(16.0-17.8 \times 10^{3} / \mathrm{mm}^{3}\right)$, except for group $\mathrm{V}\left(24.010^{3} / \mathrm{mm}^{3}\right)$ which received extract from var. Mirela lupin seeds. At the same time the percentage of lymphocytes in the blood of the birds of this group, as well of the birds of group II (fraction $A_{1}$ ), was the lowest ( 71.70 and $71.06 \%$, respectively). Leukograms of the blood of the chickens from all experimental groups revealed increased level of basophils and eosinophils compared to the birds of the control group.

The differences in the level of thyroid hormones (triiodothyronine and thyroxine) and morphological composition of the blood can be regarded as preliminary information about response of the chickens to the tested extracts

TABLE 5

Cellular fractions of blood (Experiment 2)

\begin{tabular}{|c|c|c|c|c|c|c|}
\hline \multirow[t]{2}{*}{ Components } & \multicolumn{6}{|c|}{ Groups } \\
\hline & I & II & III & IV & $\mathrm{V}$ & VI \\
\hline Erythrocytc, $10^{6} / \mathrm{mm}^{3}$ & 2.23 & 2.38 & 2.32 & 2.52 & 2.42 & 2.38 \\
\hline Haemoglobing, $\%$ & 8.1 & 8.1 & 7.9 & 8.3 & 8.5 & 7.8 \\
\hline Haematocrit, $\%$ & 28.7 & 28.7 & 28.9 & 28.1 & 28.7 & 27.3 \\
\hline Mean volume of blood cell, $\mu \mathrm{m}^{3}$ & 130.3 & 121.1 & 124.8 & 116.2 & 119.3 & 116.0 \\
\hline Disck blood, $10^{3} / \mathrm{mm}^{3}$ & 25.7 & 19.9 & 19.7 & 22.9 & 23.9 & 27.1 \\
\hline Leucocyte, $10^{3} / \mathrm{mm}^{3}$ & 17.2 & 16.8 & 17.1 & 16.0 & 24.0 & 17.8 \\
\hline \multicolumn{7}{|l|}{ Lcucogram. $\%$} \\
\hline Lymphocytes & 73.56 & 71.06 & 76.60 & 76.9 & 71.70 & 74.10 \\
\hline Heterophils & 19.45 & 18.61 & 14.3 & 15.2 & 17.5 & 16.7 \\
\hline Basocytes & 1.26 & 3.85 & 2.40 & 3.41 & 3.01 & 2.68 \\
\hline Eosinophils & 1.09 & 1.54 & 1.78 & 2.08 & 2.57 & 2.98 \\
\hline Monocytes & 4.75 & 4.94 & 5.04 & 2.45 & 5.38 & 3.79 \\
\hline
\end{tabular}

A, B - P $\leqslant 0.01 ; a, b-P \leqslant 0.05$ 
from $L$. angustifolius var. Mirela and Emir seeds and fractions of var. Mirela lupin extracts. In the case of the extracts the effects could be caused both by alkaloids as well as by other compounds resulting in synergic reactions. This phenomenon requires further studies. Evaluation of the effect of the fractions is hindered by the occurrence of the alkaloids in the form of hydrochlorides (fraction $\mathrm{A}_{5}$ ), acetates or other salts, that is compounds differing from the native forms occurring in the seeds. Interpretation of the results is also difficult due to differences in alkaloid content in extracts of the same variety (Mirela) of L. angustifolius in Experiments 1 and 2.

\section{REFERENCES}

Bednarczyk M., Karasinski D., Mazanowski A., Gulewicz K., 1987. Preliminary observations on the influence of alkaloids present in the seed extract of hupine (Lupinus angustifolius) on the embryogenesis and selected physiological indicators of duck embryonic blood. Arch. Geflügclk. $51,185-189$

Bednarczyk M., Karasiński D., Michalski Z., Markiewicz M., Gulewicz K., 1989. The influence of lupin alkaloids on reproductive features of duck. Lupin Newsletter 13, 66-73

Bednarczyk M., Lisowski M., Siwek M., Uziębło L., Stobiecki M., Gulewicz. K., 1996. Estimation of influence of different groups of chemical compounds from Lupinus angustifolius seed on development of chicken embryo. Bull. Pol. Acad. Sci., Ser. Biol. (in press)

Błaszczyk B., Stobiecki M., Kowalczyk-Bronisz S.H., Gulewicz K., Szymaniec S., 1994. Immunotropic activity of lupin seeds extracts and fractions from Lupinus angustifolius and Lupinus albus. Arch. Immunol. Ther. Exp. 42, 147-153

Bomski H., 1989. Basic Hacmatological Investigations (in Polish). PZWL, Warszawa

Gulewicz K., 1988. The utilization of protein and other nutrients of bitler lupin seeds (in Polish). Thesis. Editor - Institutc of Bioogramic Chemistry, Polish Academy of Sciences, Poznań

Gulewicz K., 1991. Method of debittering of lupin seeds. Polish Patent No. 152, 748

Guillaume J., Chenieux J.C., Rideau N., 1979. Feeding value of Lupinus albus L. in chicken diets with emphasis on the role of alkaloids. Nutr. Rep. Int. 20,57

Hill G.D., 1977. The composition and nutritive value of lupin seeds. Nutr. Abstr. Rev., Ser. B. 47, 511.529

IJill G.D., Pastuszewska B., 1993. Lupin alkaloids and their role in animal nutrition (in Polish). Lupin-Protcin-Ecology. Proccedings of 1st Polish Scientific Conference, Poznań (Poland), pp. 9-38

Karasiński D., Bednarczyk M., Perctiatkowicy M., Gulewic\% K., 1988. The influence of alkaloids in seeds of Lupinus angustifolits on the growth and some meat features of duck. Bull. Pol. Acad. Sci., Ser. Biol. 36, 215-224

Kliber A., Chichłowska J., Szkudelski T., Gulewicz K., Stobiccki M., 1994. Influence of extract from bitter lupin ( $L$. angustifolius) seeds on some endocrine glands. Proceedings of International Euro Food Toxicology IV Con Terence 2, 424-429

Markiewicz M., Kolanowska A., Gulewicz K., 1988. The chemical composition of the debittered lupine seeds and their extract. Bull. Pol. Acad. Sci., Ser. Biol. 36, 13-24

Nutrient Requirements of Poultry. Nutritive Value of Feeds (in Polish), 1993. IInd ed. The Kielanowski Institute of Animal Physiology and Nutrition (Editor), Jabłonna 
Pastuszewska B., 1985. Factors affecting nutritive valuc of field bean, pea and lupin for monogastric animals (in Polish). Thesis. Ossolineum, Wroclaw, pp. 1-140

Peretiatkowicz M., Markiewicz M., Wojtaszek P., Stencel M., Kolanowska A., Twardowski T., Gulewicz K., 1987. The treatment of lupin sceds for thcir utilization as fodder. Lupin Newsletter $10,31-35$

Perctiatkowicz M., Ciesiołka D., Stobiecki M., Gulewicz K., 1993. Biological activity of extract from bitter lupin seeds. Proceedings of 7th International Lupin Conference, Evora, pp. 17-23

Ruiz L.P., White S.F., Hove E.L., 1977. The alkaloid content of sweet lupin seed in feeding trials on pigs and rats. Anim. Fecd Sci. Tcchnol. 2, 59-66

Skulmowski J., 1974. Methods of Fstimation of Feedstuffs Composition and Quality (in Polish). PRWiL, Warszawa

Stobiecki M., Gulewicz K., 1991. Polish Patent 22 PAN 91

Stobiccki M., Błaszczyk B., Kowalczyk-Bronis; S.II., Gulewicz K., 1993. The toxicity of seed extracts and their fractions from Lupinus angustifolius L. and Lupinus albus L. J. Appl. Toxicol. $13,347-352$

Uriębło L., Gulewicz K., Tarasewicz Z., Bednarczyk M., Szczerbińska D., Ligocki M., 1995. The biological evaluation of lupinc cxtracts used in chickens and breeding hens feeding. In: J. Frencel, K.Gulcwicz (Editors). Advances in lupin investigation. Polish Lupin Association, Institute of Bioorganic Chemistry, Polish Academy of Sciences, Poznań (Poland), pp. 89-98

Vogt H., Harnisch S., Krieg R., Rauch H.W., 1983. Use of lupine meal in laying-hen feed after partial extraction of alkaloids. Anim. Res. Dev. 18, 47-54

\section{STRES7CZENIE}

Wpływ podawania kurczętom ekstraktów z nasion lubinu o różnej zawartości alkaloidów oraz. frakcji ekstraktu $z$ hubinu gorłkiego na tempo warostu, poziom hormonów oraz obraz krwi ptaków

Kogutom typu brojler od 3-8 tygodni odchowu podawano per os ckstrakt i izolowane, różniące się skladem chemicznym frakcjc ckstraktu $\left(\mathrm{A}_{0}-\mathrm{A}_{6}\right) \mathrm{z}$ nasion lubinu gorzkiego L. angustifolius $\mathrm{v}$. Mirela (dośw. 1) oraz ckstrakt i wybrane frakcje $\left(A_{1}, A_{3}, A_{5}\right)$ z nasion tej odmiany, a także ekstrakt z łubinu słodkiego v. Finir (dośw. 2). Użyte w doświadczeniach ekstrakty z lubinu gorzkicgo ze zbioru zdwóch kolejnych lat różniły się zawartością alkaloidów. Ekstrakty i frakcje nic wpłynçły ujemnie na wzrost, zużycie paszy i stan zdrowotny kurcząt. Jedynie w dośw. 2 frakcja $A_{s}$ (chlorowodorki alkaloidów), pochodząca z ekstraktu o większej zawartości alkaloidów, spowodowała zmniejszenie $(\mathrm{P}<0,01)$ przyrostów masy ciała kogutów.

Poziom $\mathrm{T}_{3}$ w surowicy krwi obwodowcj byl najniższy u kurcząt otrzymujących frakcję z cukrami $\left(\mathrm{A}_{3}\right)$, a najwyższy w grupic otrzymującej chlorowodorki alkaloidów $\left(\mathrm{A}_{5}\right)$, poziom $\mathrm{T}_{4}$ był najwyższy u kurcząt otrzymujących ekstrakt \% fubinu stodkiego. Ekstrakty i frakcje nie miały wpływu na obraz czerwonokrwinkowy, w leukogramach krwi stwierdzono natomiast wystepowanie nieukicrunkowanej zmienności, z wyjątkiem zawartości bazofili i eozynofili, których udział we krwi kurcząt z grup doświadczaInych był wyższy niż u ptaków grupy kontrolncj. 